\title{
The Experimental Inoculation with Leprosy Bacillus in Various Hybrid Nude Mice (Continued): The Results of CD-1(ICR) Hybrid Nude Mice
}

\author{
KAZUNARI NAKAMURA and YASUKO YOGI \\ (National Institute for Leprosy Research)
}

(Received for Publication: July 23, 1988)

\begin{abstract}
Key words: Mycobacterium leprae, experimental lepromatous leprosy model, CD-1(ICR) hybrid nude mice
\end{abstract}

We have successfully established as an animal model for experimental lepromatous leprosy by using NFS/N nude mice originating from a Swiss colony $\left({ }^{1}\right)$ and SHR nude rats originating from a Wistar colony ${ }^{4}$ ). In addition, non-obese diabetic (NOD) hybrid nude mice originating from Swiss-Webster mice (Jcl: ICR outbred strain), which gave excellent results with the development of a marked lepromatoid lesions as compared with that of "resistant" Crj: CD-1(ICR) or Jcl : ICR nude mice $\left(^{3}\right)$.

In this report, we compared the susceptibility of $\mathrm{CD}-1$ (ICR) and Jcl : AF hybrid nude mice originating from the same Swiss-Webster (ICR outbred) mice with that of "resistant" CD-1(ICR) nude mice.

\section{Materials and Methods}

We have established CD-1(ICR) hybrid nude mice $\left(M_{1}\right)$ by mating the CD-1 female mice and NFS/N or $\mathrm{N}$ : NIH (s) male nude mice. Jcl: AF hybrid nude mice (IAI inbred female mice originating from $\mathrm{Jcl}$ : ICR outbred strain) were obtained from CLEA, Tokyo, Japan. CD.1(ICR) hybrid nude mice (4-7 weeks old, 10 nude mice, respectively) and $10 \mathrm{CD}-1$ (ICR) nude mice 4.7 weeks old were used as control group. The inoculum size was $5.2 \times 10^{5}$ bacilli/foot derived from hind foot passage of $\mathrm{Crj}$ : CD-1(ICR) nude mice. Experiment of Jcl : AF hybrid nude mice were performed separately. Ten Jcl : AF nude mice and $\mathrm{CD}-1(\mathrm{ICR})$ nude mice (6 male, 7 female) $4-5$ weeks old were used. Inoculum size was $7.8 \times 10^{5}$ bacilli/foot derived from passage of $\mathrm{Jcl}:$ ICR nude mice. The site of injection was the right hind footpad. Mice were maintained in the vinyl isolator under specific pathogen free (SPF) conditions, and were provided with sterilized autoclavable commercial diet (CE-2, CLEA, JAPAN) and tap water ad libitum. For identification, the harvested acid fast bacilli (AFB) were reinoculated into the right hind foot of Jcl: ICR mice in order to confirm the growth pattern (persistent infection with microglobi). The AFB obtained were cultured on 1\% Ogawa's medium and a modified Nemoto's egg yolk medium at $33^{\circ} \mathrm{C}$ and $37^{\circ} \mathrm{C}$ for 3 months. The smears of $\mathrm{AFB}$ were treated with pyridine 


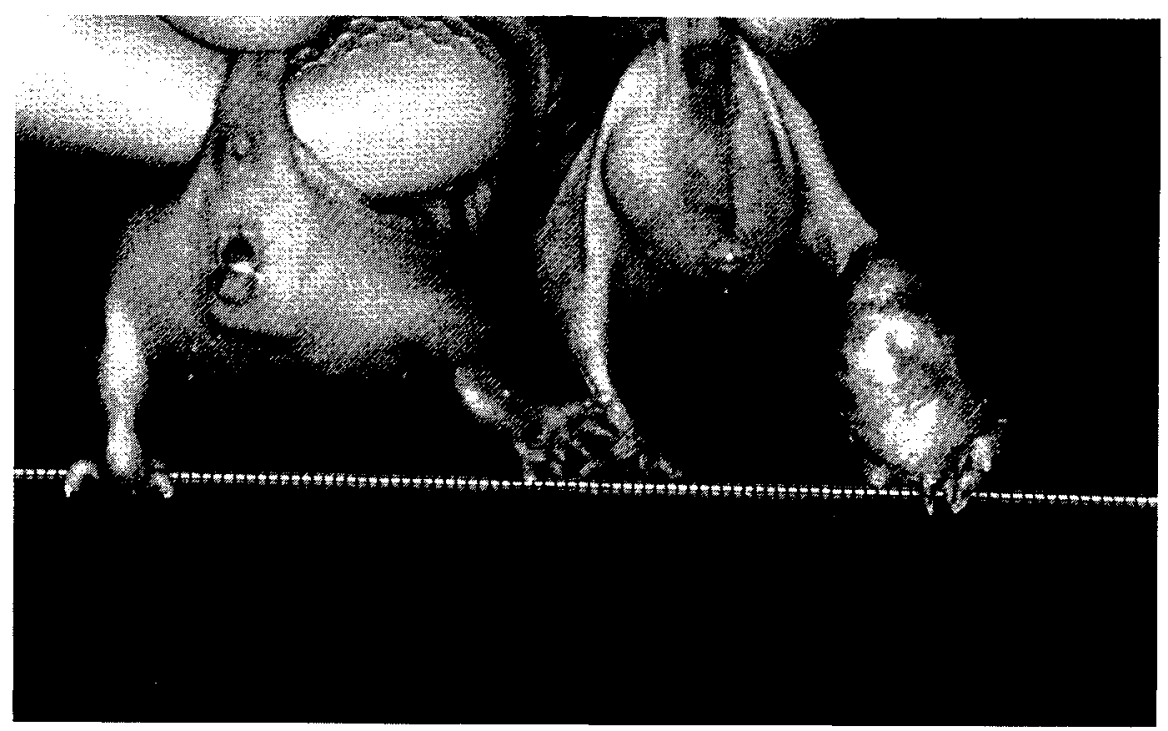

Fig. 1 Swelling of the right hind foot, site of inoculation, + swelling foot shows on the left nude mouse, and $\mathbb{H}$ swelling foot due to $M$. leprae growth shows on the right nude mouse.

Table 1 Inoculated right hind foot swelling due to the growth of $M$. leprae in the hybrid nude mice

\begin{tabular}{|c|c|c|c|c|c|c|c|c|c|c|c|c|}
\hline \multirow{3}{*}{$\begin{array}{c}\begin{array}{c}\text { Days afyer } \\
\text { inoculation }\end{array} \\
242\end{array}$} & \multicolumn{12}{|c|}{ Genetic background of nude mice } \\
\hline & \multicolumn{4}{|c|}{ CD-1(ICR) } & \multicolumn{4}{|c|}{$\mathrm{CD}-1 \times \mathrm{NFS} / \mathrm{N}$} & \multicolumn{4}{|c|}{$\mathrm{CD}-1 \times \mathrm{N}: \mathrm{NIH}(\mathrm{s})$} \\
\hline & H & + & + & \pm & H & H & m & 世 & H & m & m & \# \\
\hline & \pm & \pm & \pm & \pm & H & H & H & $H$ & $H$ & $H$ & H & \\
\hline \multirow[t]{2}{*}{434} & 世 & 世 & 世 & $H$ & Wl & m & H & \# & H & W & 世 & HW \\
\hline & H & H & + & & $\mathrm{WH}$ & H & & & H & & & \\
\hline
\end{tabular}

Note; Inoculum size $\cdots \cdots . .5 .2 \times 10^{5}$ bacilli/foot

as modified by us. Besides, the tissues obtained from infected nude mice were fixed in buffered formaldehyde solution, and stained with Fite-Faraco, and Heamatoxylin-Eosin.

\section{Results}

As shown in Fig. 1, one plus swelling due to $M$. leprae growth indicate on the left nude mouse hind foot, four plus swelling shows on the right nude mouse hind foot. Also, the swelling shows due to $M$. leprae growth in injected hind foot of CD-1(ICR) hybrid nude mice and CD-1(ICR) nude mice are given in Table 1 at 242 days and 434 days after injection. At 434 days after injection, there were marked nodular lesions in the infected foot, developing to the lower leg and toes of $\mathrm{CD}-1(\mathrm{ICR}) \times \mathrm{NFS} / \mathrm{N}$ and $\mathrm{CD}-1$ $(\mathrm{ICR}) \times \mathrm{N}: \mathrm{NIH}(\mathrm{s})$ hybrid nude mice $\left(\mathrm{M}_{1}\right)$ indicating no significant differences against susceptibility to $M$. leprae in either mouse group. In contrast, CD.1(ICR) nude mice showed 
Table 2 Inoculated right hind foot swelling due to the growth of $M$. leprae in the AF hybrid nude mice

\begin{tabular}{|c|c|c|c|c|c|c|c|c|}
\hline \multirow{3}{*}{$\begin{array}{l}\begin{array}{c}\text { Days after } \\
\text { inoculation }\end{array} \\
300\end{array}$} & \multicolumn{8}{|c|}{ Genetic background of nude mice } \\
\hline & \multicolumn{4}{|c|}{ CD-1(ICR) } & \multicolumn{4}{|c|}{$\mathrm{AF}(\mathrm{IAI} \times \mathrm{NFS} / \mathrm{N})$} \\
\hline & $H$ & $H$ & $H$ & + & $\mathrm{HH}$ & H & H & HF \\
\hline & + & + & + & + & H & $H$ & $H$ & + \\
\hline & + & \pm & \pm & & & & & \\
\hline \multirow[t]{2}{*}{433} & $H$ & $H$ & H & H & H & H & $H+$ tht & 册 \\
\hline & H & H & $H$ & + & H & H & $H$ & \\
\hline
\end{tabular}

Note; Inoculum size $\cdots \cdots 7.8 \times 10^{5}$ bacilli/foot

lesions with a slight swelling at the infected paw.

As shown in Table 2, the swelling due to $M$. leprae growth of $\mathrm{Jcl}$ : AF hybrid nude mice gave excellent results as compared with CD-1(ICR) nude mice at 300 days and 433 days after inoculation, as well as CD-I(ICR) hybrid nude mice, above mentioned. Thus, CD-1(ICR) hybrid nude mice and Jcl: AF hybrid nude mice were highly susceptibility to $M$. leprae as compared with $\mathrm{CD}-1(\mathrm{ICR})$ nude mice originating in spite of the same SwissWebster mice (ICR outbred strain). The AFB isolated from the swollen tissues were distingushed from other mycobacteria, namely, the reinoculation test by using Jcl: ICR normal mice indicated with persistent resistant infection only at the site of injection; loss of acid-fastness by pyridine extraction; the cultivation on a modified Nemoto's egg yolk medium as well as on $1 \%$ Ogawa's medium at $33^{\circ} \mathrm{C}$ and $37^{\circ} \mathrm{C}$ for 3 months which showed no growth. In addition, sections of he inoculated feet of $\mathrm{CD}-1(\mathrm{ICR})$ and $\mathrm{Jcl}: \mathrm{AF}$ hybrid nude mice showed the presence of severe lepromatoid lesions, when stained with FiteFaraco and Haematoxylin -Eosin as compared with CD-1(ICR) nude mice. Therefore, we have established the CD-1(ICR) hybrid nude mice and Jcl : AF hybrid nude mice at the $\mathrm{M}_{1}$ circle as a new model for experimental lepromatous leprosy, resembling the cases of ICR-Lasat and their athymic counterparts, and NOD hybrid nude mice as compared with that of "resistant" CD-1(ICR) nude mice.

\section{Discussion}

We showed as an animal model for experimental lepromatous leprosy, such as NOD hybrid nude mice originated from Swiss-Webster mice (Jcl: ICR outbred strain)( $\left.{ }^{5}\right)$ and $\mathrm{NFS} / \mathrm{N}$ and $\mathrm{NIH}(\mathrm{s})$ nude mice originated from Swiss mice ${ }^{(2,4)}$. In addition, CD-1(ICR) hybrid nude mice; CD-1(ICR) $\times \mathrm{NFS} / \mathrm{N}, \mathrm{CD}-\mathrm{l}(\mathrm{ICR}) \times \mathrm{N}: \mathrm{NIH}(\mathrm{s})$ and IAI inbred strain orginated from Jcl: ICR mouse by mating the cross-intercross system ( $\mathrm{M}_{1}$ circle) with $\mathrm{CD}-1$ outbred strain or IAI inbred strain female and NFS/N or $N$ : NIH(s) male nude mice, they were produced highly susceptibility to $M$. leprae. Rice and O'brien reported that the genetic variance of laboratory outbred Swiss mice $\left.{ }^{6}\right)$. However, in spite of the fact these mice originated from a Swiss or Swiss-Webster colony, gave excellent results with the development of marked 
lepromatoid lesions, resembling NFS/N and $\mathrm{N}: \mathrm{NIH}(\mathrm{s})$ nude mice originating a Swiss strain. Thus, the formation of lepromatoid lesions in the Swiss and Swiss-Webster hybrid nude mice $\left(\mathrm{M}_{1}\right)$ may be produced by the genetic background except for CD-1(ICR) nude mice. The same may be true for SHR hybrid nude rats originating from the Wistar colony which differ from "resistant" WKY, WM, and LOU nude rats in experimental lepromatous leprosy.

\section{Summary}

Hybrid nude mice by mating with CD-1(ICR) outbred and IAI inbred strain originating Jcl : ICR strain female and NFS/N inbred or N: NIH (s) outbred nude male mice, they were given excellent results with the development of marked lepromatoid lesions in comparison with that of "resistant" $\mathrm{CD}-\mathrm{I}(\mathrm{ICR})$ nude mice. In summary, we have established $\mathrm{CD}-\mathrm{I}(\mathrm{ICR}) \times \mathrm{NFS} / \mathrm{N}, \mathrm{CD}-1(\mathrm{ICR}) \times \mathrm{NIH}(\mathrm{s})$ and $\mathrm{IAI} \times \mathrm{NFS} / \mathrm{N}$ hybrid nude mice at the $\mathrm{M}_{1}$ circle (generation) as a new model for the experimental lepromatous leprosy. The development of marked lepromatoid lesions formation in nude mice may be produced by the genetic background of the Swiss colony except for CD-I(ICR) nude mice.

\section{Acknowledgements}

This study was supported in part by grants from the U. S. -Japan Cooperative Medical Science Program and the Sasakawa Memorial Health Foundation, and the results of CD-1 (ICR) and Jcl : AF hybrid nude mice described in Ann. Rep. for Lep. Res. Tokyo. pp. 31-35 (1987). (In Japanese)

\section{References}

1) Nakamura, K. and Yogi, Y.: The nude mouse as an experimental lepromatous leprosy model (continued): The NFS/N nude mouse as a new model using the intra-upper lip inoculation method. Int. J. Lepr., 50, 585, (1982).

2) Nakamura, K. and Yogi, Y.: The hereditaly asplenic athymic (LASAT) mouse as an experimental lepromatous leprosy model (continued): Role of the spleen in the formation of the lepromatoid lesion. Int. J. Lepr., 50, 586, (1982).

3) Nakamura, K. and Yogi, Y.: The nude rat as an experimental lepromatous leprosy model (continued): The effects of carrageenans splenectomy, and treatment with thymus cells. Int. J. Lepr., 50, 587-588, (1982).

4) Nakamura, K., and Yogi, Y. The athymic rodent as an experimental lepromatous leprosy model (continued): The SHR nude rat as a new model and the effect of host in the formation of the lepromatoid lesions in nude mice. Int. J. Lepr., 52, 605-606, (1984).

5) Nakamura, K. and Yogi, Y.: $M$. leprae-susceptibility of NOD hybrid nude mice. Int. J. Lepr., 55, 787-788, (1987).

6) Rice, M. C. and $\mathrm{O}^{\prime}$ brien, S. J.: Genetic variance of laboratory outbred Swiss mice. Nature, 283, 157-161, (1980). 


\title{
雑種ヌードマウスへのらい菌接種（続報） CD-1 (ICR) 雑種ヌードマウスの成績
}

\author{
中 村一成與儀ヤス子
}

キーワード：らい菌, 実験的らい腫らいモデル，CD-1(1CR) 雑種ヌードマウス

ヌードマウスの遺伝的背景の遺伝子が異なるとらい腫 らい病巣の形成能も異なることを始めて明らかにし得 た。すなわち，スイス系で純系である NFS/N ヌード マウスは outbred のN : NIH(s) ヌードマウスと同様, らい腫らい病巣の形成が高く, 感受性能が良好であった のに対し，同様にスイス系である outbred の Jcl : ICR ヌードマウスおよび C r j : CD-1 ヌードマウスはいずれ もらい腫らいの形成能は軽度でらい菌に対し “抵抗性” であった。しかしながら，Jcl：ICR より分離・系統化 された NOD マウスに Crj: CD-1(1CR) のヌード遺 伝子を導入した雑種ヌードマウスはらい菌に高い感受性 能を有することを明らかにし得た。

そこで本報では，NFS/N およびN : NIH(s) ヌード マウスの雄を用いてのクロスインタークロス方式により 雑種ヌードマウス（M $\left.\mathrm{M}_{1}\right)$ を作出した。一方，クレアで
は Jcl：ICR マウスより分離・系統化した IAI と雄 の NFS/N ヌードマウスとの雑種ヌードマウス $\mathrm{Jcl}$ ： AF-nuを開発市販しているので購入し,らい菌に対する 感受性能をそれぞれ検討したところ,らい腫らい病巣の 形成能が高いことが判明した。この知見は，既報のICR ラザットマウスを作出する過程で得られた同胞ヌードマ ウスが，らい菌感受性能がよいこと，さらにヌードラッ トでむ遺伝的背景が同じウイスター系であるのに SHR 雑種ヌードラット注らい菌感受性能が高いのに対し, WKY, WM，あるWは LOU/N 雑種ヌードラットで は感受性能が低いことを解明し得たことを考え合せると 興味ある免疫遺伝学的知見と考えられる。従って，今後 さらにらい菌感受性能あるいは “抵抗性” の遺伝的解析 を続行し，その生体防御の機能を究明してみたい。 